\title{
CHEMICAL DEPOSITS ASSOCIATED TO METAVOLCANOSEDIMENTARY SEQUENCES OF THE CENTRAL PORTION OF THE SÃO FRANCISCO CRATON IN THE STATE OF BAHIA, BRAZIL: A REVIEW
}

\section{ILSON GUIMARÃES CARVALHO}

\begin{abstract}
Supracrustal suites of metavolcanosedimentary rocks (SC) occur in the central portion of the São Francisco Craton in the State of Bahia. They were primarily formed by calc- alkaline to perialkaline volcanic flows and tuffs, clastic and chemical sediments. The latter are referred to the banded iron (BIF), iron-manganese (BIMF) and manganese (BMF) formations, iron-poor magnesian-rich carbonate formation (IPMRCF), and minor metacherts. BIF and IPMRCF are present in all the reported SC. BIF is typified by the presence of the oxide, carbonate and silicate facies. Occurrences of the sulfide facies are reported for the Sobradinho-Salitre and the Boquira SC. The burial metamorphism and thermal effects pronounced by the Transamazonian migmatization and granitization are accountable for the generation of amphibolites, epidosites, steatite and talc schists, phyllites, sandstones, quartzites, itabirites, metamorphic limestones to include banded carbonates, marbles and calc-silicate rocks. It is suggested that the deposition was similarly processed throughout an extensive crustal segment and that it was part of the cratonic evolution occurred during the end of the Archean to the beginning of the Proterozoic.
\end{abstract}

Keywords: São Francisco Craton,, Paleoproterozoic, metavolcanosedimentary sequences, BIF, banded iron-manganese formations, magnesite

INTRODUCTION The Archean gneissic migmatitic terrains of Central Bahia are typified by the association with metavolcanosedimentary sequences which are in this paper termed supracrustal complexes and indicated by SC. These SC are named in accordance to the their geographical distribution (Fig. 1). So, from the north to the south, they are called Sento Sé-Remanso, Casa Nova, Sobradinho, Salitre, Xique Xique, Boquira, Riacho de Santana, Caetité, Ibitira, Brumado, Umburanas, Contendas, Mirante, Guajerú, Urandí, Licínio de Almeida and Jacarací. They include a complex association of metavolcanic rocks and derived schists plus clastic and chemical sediments. The common geological features reported for the latter support the idea that they were generated by similar processes that took place from the end of the Archean to the beginning of the Proterozoic (Carvalho et al. 1997) and throughout an extensive but already individualized crustal segment. The structural relationship between the Archean basement and the SC suggests that they are associated to each other in a similar way to that one reported in the Rhodesian craton of Africa and the Yilgarn block of Australia for their substratum and the Archean greenstone belts (Phaup 1973, Turek and Compston 1970,

Mascarenhas 1976). During the Transamazonian a tectonothermal episode occurred in this portion of the S. Francisco Craton and it

was marked by migmatization and granitization. A good evidence of these crustal recycling processes is presented by Pinto et al. (1998). The Middle Proterozoic Espinhaço Supergroup is deposited on these migmatized terranes of Central Bahia and it is stratigraphically succeeded by the Neoproterozoic São Francisco Supergroup. Younger unconsolidated Phanerozoic sediments cover the rest of the area.

With the purpose of sheding some more light on the knowledge of the chemical deposits, in this paper they are reviewed mainly

based on more recent data to including data from microanalyses of minerals. These analyses were performed at the Universidade de Campinas -UNICAMP by using an EDS equipment set to operate with 100 seconds exposure time, tension of $25 \mathrm{kV}$ and I-probe of $7 \mathrm{nA}$ and at Universidade Federal da Bahia-UFBA by using a microprobe equipment CAMECA SX50.

THE BASEMENT The lithotypes of the cratonic basement include granulites, granoblastites, migmatites and gneisses that exhibit a wide range variation in composition being granodioritic and adamellitic the most common ones. Deposited on it are the SC. The intrusive plutons include granites, monzonites and syenites and they were emplaced from 2.2 to 1.7 Ga. (Jardim de Sá et al. 1976, Brito Neves et al. 1980, Mascarenhas and Garcia 1989). In more recent works, Paim et al. (1998) found an age of $2.1 \mathrm{Ga}$ from $\mathrm{Pb} / \mathrm{Pb}$ isochron obtained for the older syenitic lithofacies, termed Cara Suja, and Leahy et al. (1998) found the age of $1.7 \mathrm{Ga}$ for the youngest magmatic pulses of the Ceraima syenite. Both Cara Suja and Ceraima syenites are part of the evolutionary history of the huge Guanambi-Urandi batholith that cuts and metasomatized the Urandi and Riacho de Santana SC. Pinto et al (1998) found an age of $2.0 \mathrm{Ga}$ from $\mathrm{Pb}-\mathrm{Pb}$ isochron on monazite from a peraluminous granite which was generated from thermal reworking (block collision) of the Archean crust and intruded the Umburanas SC.
Remnants of the lithofacies of the SC that were deeply metasomatized and locally almost entirely eroded occur as lens like bodies that are spread all over the gneissic-migmatitic terranes. These metasomatized lithotypes are much more frequent at the proximities of the well preserved piles of the $\mathrm{SC}$ and near the metatexites and intrusive bodies.

\section{THE LITHOFACIES OF THE SC AND THE FACIES} VARIATIONS OF THE CHEMICAL DEPOSITION The SC comprise rocks derived from volcanic flows and tuffs, and from chemical and clastic sediments. The latter include grey to greenish phyllites, sandstones, quartzites and probably part of the schistose rocks. Locally, in the Sento Sé and Contendas-Mirante SC this suite of rocks prodominates in the upper portion of the stratigraphic column (Souza et al. 1979, Marinho 1991). Mafic volcanic terms are reported at the lower units of the Contendas-Mirante (Marinho 1991) and Sobradinho (Silva and Cunha 1999) SC. Cunha and Froes (1994) reported spinifex textured komatiitic flows at the base of the

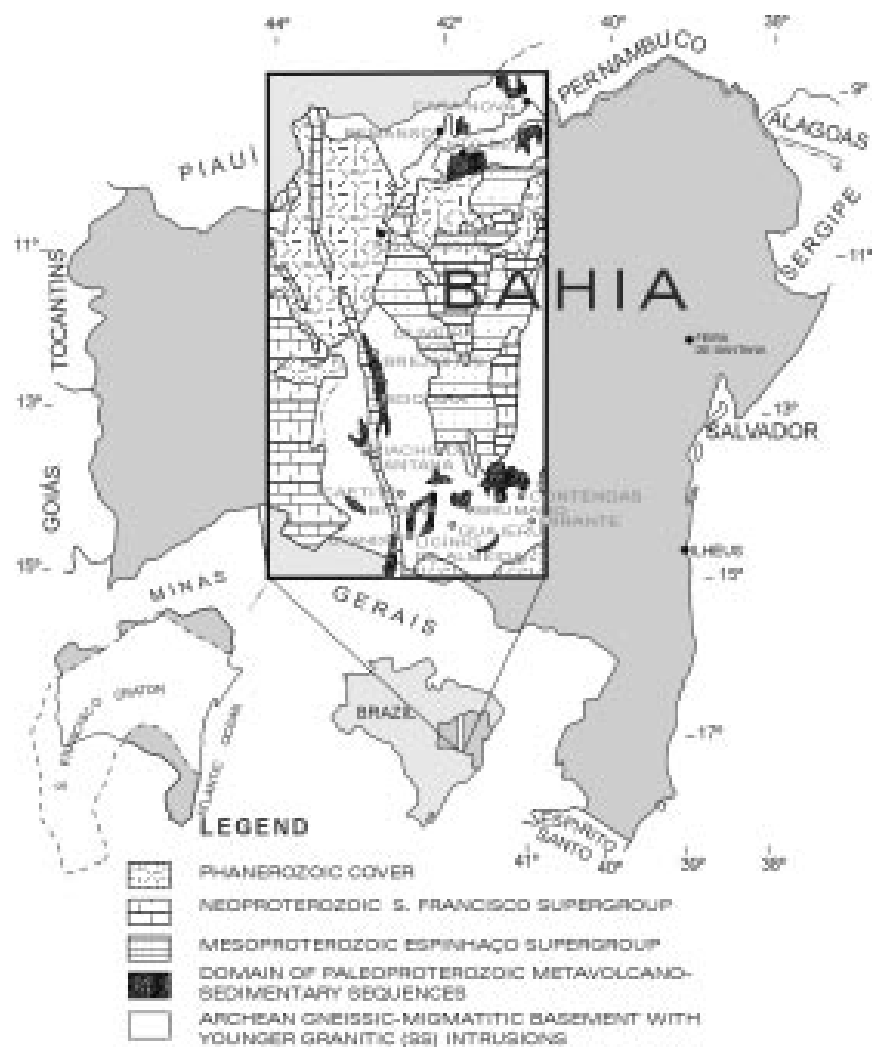

Figure 1 - General geology of the central portion of the S. Francisco Craton in the State of Bahia (modified after Inda and Barbosa 1978). 
Umburanas SC. The intermediate to acidic volcanic rocks have an alkaline to perialkaline character. The volcanic rocks were almost entirely altered by the granitization-migmatization processes. into schistose materials, including quartz-mica, quartz-sericite, quartzchlorite, quartz-biotite, muscovite, chlorite and garnet schists. Carvalho (1982) and Carvalho et al. (1982) described the rocks that were derived from the chemical sediments. From the shallow to the deep depositional zone these rocks include: metachert, ferrugineous quartzites and orthoquartzites, itabirites, banded carbonatesamphiboles-martite and amphiboles-magnetite lithotypes. Table 1 summarizes some records for the chemical sedimentary facies.

Based on the chemical composition, the chemical metasediments are classified into the following groups of rock suites: banded iron formation (BIF), banded iron-manganese formation (BIMF), banded manganese formation (BMF), iron-poor magnesian-rich carbonate formation (IPMRCF) and metachert.

The facies of BIF The BIF are typified by the presence of the oxide, carbonate and silicate facies. The sulfide facies are reported for the Boquira SC where it constitutes de massive $\mathrm{Pb}-\mathrm{Zn}$ ore (Carvalho et al. 1982,1997) and for the Sobradinho-Salitre SC (Silvaand Cunha 1999) The oxide facies is composed of quartz-rich and iron oxides-rich bands which are alternately distributed within several scales of thickness (Carvalho and Albuquerque 1996). Hematite is the main iron oxide mineral and it may occur along with martite in proportions that tend to increase going towards the carbonate facies. Besides martite, the presence of amphiboles and iron- rich carbonates indicates this transitional zone. The presence of any other mineral is indicative of hydrothermal action. Figure 2 is the electronic micrography obtained from a lithotype of the oxide facies that occurs at the Boquira mine nearby an apophysis of intrusive granite. The presence of biotite, apatite and ferrithorite as it is shown in this micrography is an evidence of the hydrothermal effect on this facies. and in Figure 3 are the EDS spectra obtained for the minerals that are shown in Figure 2. The carbonate facies is basically composed of magnesian carbonate-rich bands that are alterned to iron oxide (martite overwhelmshematite)rich bands. Both kind of bands bear a varietal amount of amphiboles.
The metasomatism is much more pronounced in this facies than in the oxide one and this is due the more reactive character of the carbonates compared to both quartz and martite-hematite. The metasomatic effect may be observed by the generation of talc, amphiboles of the tremoliteactinolite series, diopsideand scapolite. At the vicinities of metatexites and the intrusive granites, mineral changes may led to the formation of calc-silicatelithotypes that represent true hornfels. Table 2 shows the composition obtained from electronic microprobe on carbonate and silicate minerals which are frequently reported in these and others studied lithofacies.

The $\mathrm{FeO}$ contents in the carbonate minerals rarelly exceed $8.70 \%$, falling in the compositional field of Fe-dolomite. Figure 4 is a $\mathrm{CaO}$ -

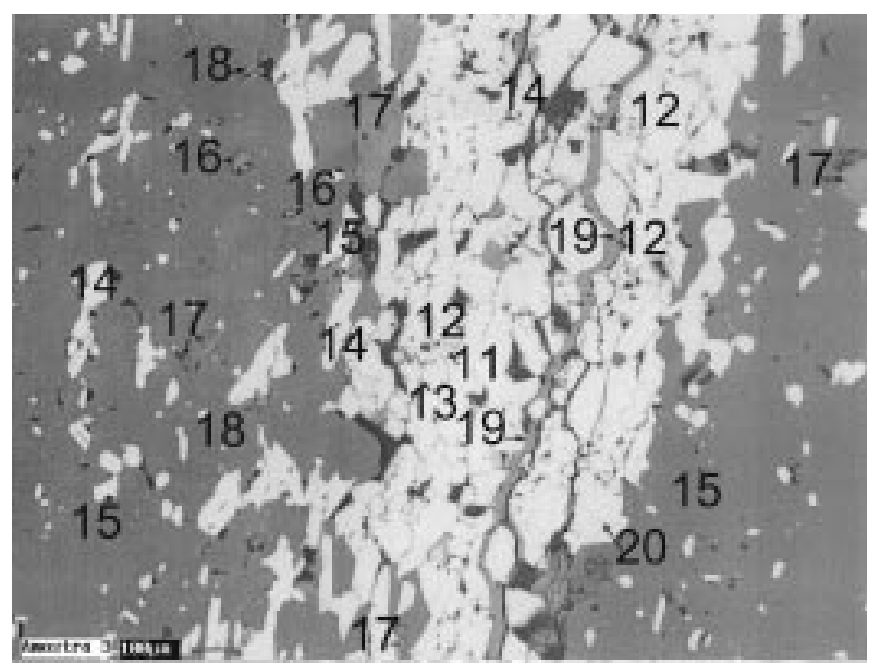

Figure 2 - EDS - Micrography of oxide facies from the Boquira Complex. The analised minerals are: Ferrithorite (11,13), Martite (12,20), Hematite ( 14 ), Quartz ( 15 ), Biotite (16,17), Apatite (18) and Calcite (19). Polished section.
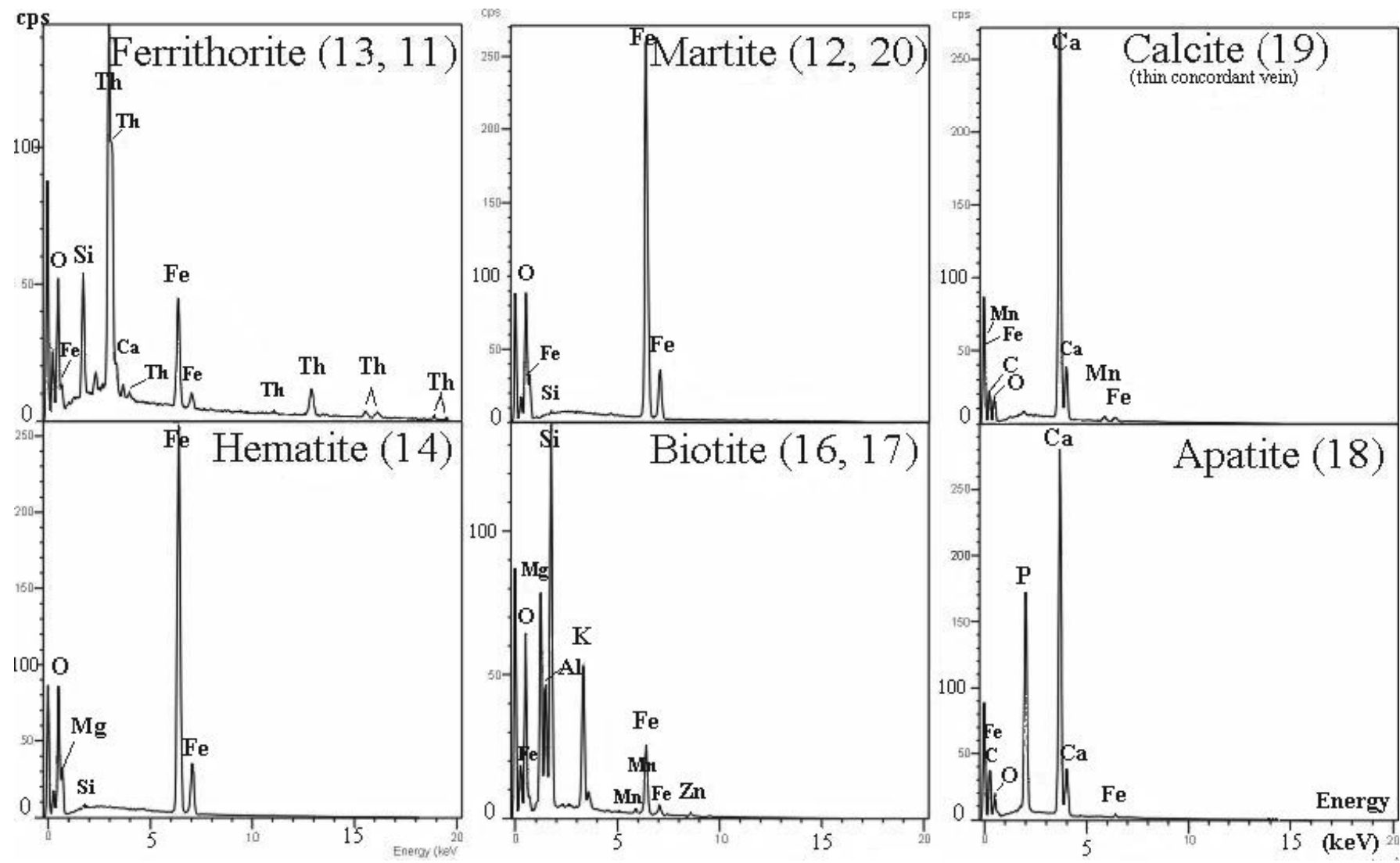

Figure 3 - EDS - Spectra from the minerals that are reported in the lithotype of the oxide facies of BIF shown in Figure 2. 
Table 1- Some stratigraphic characteristics of the chemical lithofacies (CL) that occur in the central part of the S. Francisco Craton in the Central Bahia

\begin{tabular}{|c|c|c|c|}
\hline $\begin{array}{l}\text { HOST COMPLEX } \\
\text { (SC) }\end{array}$ & $\begin{array}{l}\text { HOST UNIT(S) OF } \\
\text { THE CL }\end{array}$ & $\begin{array}{l}\text { CHEMICAL NATURE AND MAIN } \\
\text { LITHOTYPES }\end{array}$ & REFERENCES \\
\hline \multirow{4}{*}{$\begin{array}{l}\text { SENTO SÉ- } \\
\text { REMANSO- } \\
\text { XIQUE XIQUE }\end{array}$} & $\begin{array}{l}\text { Barreiro SC: } \\
\text { Baixa do Rancho Unit }\end{array}$ & $B I F$. Metachert & \multirow{4}{*}{$\begin{array}{l}\text { Inda and Barbosa } 1978 \\
\text { Souza et al.1979, } \\
\text { Moraes Filho et al.1981, }\end{array}$} \\
\hline & Colomí SC: & & \\
\hline & $\begin{array}{l}\text { Serra do Choro Unit } \\
\text { Castela Unit }\end{array}$ & $\begin{array}{l}B I F \text { - mostly oxide facies (itabirite). Metachert } \\
I P M R C F \text {-thick banks of magnesitic and dolomitic } \\
\text { marbles. Subordinate BIF and minor metacherts }\end{array}$ & \\
\hline & Serra da Capivara Unit & $B I F, I P M R C F$, itabirite, metachert & \\
\hline \multirow[t]{3}{*}{ CASA NOVA } & Barra Bonita Unit & $\begin{array}{l}\text { IPMRCF-dolomitic and calcitic marbles. Minor } \\
\text { BIF }\end{array}$ & Souza et al. 1979 \\
\hline & Macambira Unit & Pyritic carbonates. Calc silicates and tremolitites & Figueiroa and Silva $\mathrm{F}^{Q} 1990$ \\
\hline & $\begin{array}{l}\text { Minadorzinho Unit } \\
\text { Upper Unit, }\end{array}$ & $\begin{array}{l}B I F . \text { Metachert } \\
I P M R C F-\text { dolostones, marbles }\end{array}$ & $\begin{array}{l}\text { Angelim et al. } 1993 \\
\text { Souza and Teixeira } 1981\end{array}$ \\
\hline \multirow[b]{2}{*}{$\begin{array}{l}\text { SOBRADINHO- } \\
\text { SALITRE }\end{array}$} & Lower Unit & Pyritic metachert and IPMRCF -pyritized hornfels & Silva and Cunha 1999 \\
\hline & Sobradinho Unit & $\begin{array}{l}\text { Pyritic and siliceous IPMRCF- pyritic carbonates. } \\
\text { Silicate and sulfide facies. Metacherts. Hornfels. } \\
\text { komatiitic mafic-ultramafic suites at the base }\end{array}$ & Angelim et al. 1993 \\
\hline \multirow[t]{2}{*}{ BOQUIRA } & Contendas Member & IPMRCF. Mainly dolomitic marbles & \multirow{2}{*}{$\begin{array}{l}\text { Kaul 1970, Carvalho et } \\
\text { al.1982, Rocha } 1983\end{array}$} \\
\hline & Boquira Member & BIF. All BIF's facies are present & \\
\hline \multirow{2}{*}{$\begin{array}{l}\text { RIACHO DE } \\
\text { SANTANA } \\
\end{array}$} & Upper Unit & IPMRCF & \multirow[b]{2}{*}{ Silva and Cunha 1999} \\
\hline & Middle and Lower Units & BIF. Komatiitic volcanic suite in the Lower Unit & \\
\hline \multirow{2}{*}{$\begin{array}{l}\text { BRUMADO (only } \\
\text { for the Serra das } \\
\text { Éguas area) }\end{array}$} & Dolomitic Unit & $\begin{array}{l}\text { Dolomite and lens of tremolitite. Concordant lens } \\
\text { like bodies of magnesite }\end{array}$ & \multirow[t]{2}{*}{ Bondelos 1954} \\
\hline & Quartzitic Unit & Quartzites and $B I F$ & \\
\hline \multirow{3}{*}{$\begin{array}{l}\text { IBITIRA- } \\
\text { BRUMADO }\end{array}$} & Chemical Unit III & BIFItabirites. Minor banded metachert-carbonates & \multirow{3}{*}{ Oliveira et al. 1997} \\
\hline & Chemical Unit II & $\begin{array}{l}\text { IPMRCF-Calcitic, dolomitic and magnesitic } \\
\text { marbles }\end{array}$ & \\
\hline & Chemical Unit I & $B I F, I P M R C F$. Interbedded mafic suites & \\
\hline \multirow[b]{2}{*}{ UMBURANAS } & Upper Unit & IPMRCF & \multirow[b]{2}{*}{ Cunha and Fróes 1994} \\
\hline & Lower Unit & $\begin{array}{l}B I F, I P M R C F \text { - Metachert, calc silicate rocks } \\
\text { Deposited on a komatiitic suite }\end{array}$ & \\
\hline \multirow[b]{2}{*}{$\begin{array}{l}\text { CONTENDAS- } \\
\text { MIRANTE }\end{array}$} & Upper Unit & Scarce IPMRCF. Interbedded felsic volcanics & \multirow{2}{*}{$\begin{array}{l}\text { Marinho et al. 1979, 1980, } \\
\text { Cunha et al. } 1981 \\
\text { Marinho } 1991\end{array}$} \\
\hline & Lower Unit & $\begin{array}{l}I P M R C F, B I F \text { and metachert in association to } \\
\text { fully differentiated volcanic flows and tuffs }\end{array}$ & \\
\hline GUAJERÚ & Middle and Upper Units & $\begin{array}{l}B I F \text { with predominance of the oxide facies } \\
\text { (itabirite), and } I P M R C F \text { subordinate metadolomite } \\
I P M R C F \text { - marbles and metachert. Schistose } \\
\text { komatiitic ultramafic suite at the base }\end{array}$ & Bonfim et al. 1982 \\
\hline \multirow{2}{*}{$\begin{array}{l}\text { URANDÍ- } \\
\text { CAETITÉ- } \\
\text { CACULÉ-LICÍNIO } \\
\text { DE ALMEIDA- } \\
\text { JACARACÍ }\end{array}$} & Quartzitic Unit & $B I M F, B I F, m$ inor $I P M R C F$ and Gondites & \multirow{2}{*}{$\begin{array}{l}\text { Ribeiro Filho } 1973, \\
\text { Moraes et al. } 1980, \\
\text { Machado } 1983, \\
\text { Evangelista } 1994\end{array}$} \\
\hline & Schistose Unit & $\begin{array}{l}B I M F, B M F \text {, locally the presence of } M n \text {-rich } \\
I P M R C F \text { and lens-like bodies of } B I F \text { (itabirite and } \\
\text { banded silicate facies) }\end{array}$ & \\
\hline
\end{tabular}

$\mathrm{MgO}-\mathrm{FeO}$ diagram that shows the compositional distribution of the carbonates present in the BIF, BIMF and IPMRCF. The silicate facies is denoted by the alternations of amphiboles-rich with magnetite-rich bands. The more commom types of amphiboles are those of the cummingtonite-grunerite, tremolite-actinolite and hornblende series. Amphiboles from the last two series may predominate in the places affected by the metasomatism caused by granitization and migmatization. Riebeckite was described by Souza (1992) in samples of this facies from the Sento Sé SC. The presence of amphiboles is not restrict to the silicate and carbonate facies. It may be locally reported in sub-banding of the oxide facies (Fig. 5.A).

The facies of BIMF and BMF The BIMF and BMF are only reported in the southwestern portion of this part of the São Francisco craton in the State of Bahia where they occur in the Urandi, Jacarací, Licinio de Almeida, Caculé and Caetité SC. They constitute the major important source of manganese ore in the State which is known as "The Mn-Ore District of Urandí-Licinio de Almeida-Caetite", that have been the subject of several detailled studies (e.g.: Ribeiro Filho 1973, Machado 1983, Basilio and Brondi 1986, Evangelista 1994). In this Mn-district both BIMF and BMF may be in association with BIF. This stratigraphic association is reported by the occurrence of individualized concordant stratum of BIF beneath the BMF and by interbedded BIF stratum in the BIMF deposit. Figure 5.B is the electronic micrography from a hematite-cryptomelane-rich lithotype of the oxide fácies of BIMF. The EDS spectra for the major minerals are shown in the Figure 6.

The facies of IPMRCF This kind of chemical sedimentary formation has a wide stratigraphical distribution. This is a striking characteristic of the SC which are considered in this paper, in spite of it may be limited to scarce narrow lens in some areas. This scarcity may be due to the "metasomatic assimilation" by the granitization and migmatization that took place in the older basement and that led to the formation of the calc-silicate hornfels.

The siliceous facies It occurs as metachert and quartzite and may contain accessory or varietal amounts of carbonate, iron oxide and silicate minerals that may be concentrated in poor defined bands . The different degree of recrystallization is indicative of the distinct metamorphic strains to which these metasediments were submitted. Some types of silicified rocks that are reported in association to the hornfels are the product of the siliceous metasomatism of the chemical sediments. This kind of metasomatism is also pointed out by Carvalho (1998) as being responsible for the talc generation in places where this process affect mafic-ultramafic rocks, the silicate and carbonate facies of BIF and BIMF and the carbonates of the IPMRCF.

GEOCHEMICAL FACIES MODEL As discussed by Carvalho and Albuquerque (1996), there is no major geochemical distinction 
Table 2 - Chemical composition from electronic microprobe of some minerals which are reported in the lithofacies associated to the metavolcanosedimentary complexes of Central Bahia. The values are in percentage and they represent the average content of the element expressed in the oxide form. Each line corresponds to determinations on grain minerals found in the polished thin section made from the quoted lithofacies. nd $=$ not detected.

\begin{tabular}{|c|c|c|c|c|c|c|c|c|c|c|c|c|c|c|c|}
\hline COMPLEX & ACIES & & 1 & $\mathrm{a}_{2} \mathrm{C}$ & ${ }_{2} \mathrm{O}_{3}$ & $\mathrm{SiO}_{2}$ & ec & & & $\mathrm{K}_{2} \mathrm{C}$ & & $\mathrm{Cr}_{2} \mathrm{O}$ & 10 & n & \\
\hline Sento Sé & BIF-Oxide F. & Hematite & nd & .06 & .02 & .60 & 89.17 & .02 & nd & .01 & nd & nd & nd & .21 & 90.09 \\
\hline Sento Sé & BIF-Oxide F. & Hematite & nd & nd & .02 & nd & 89.78 & nd & .05 & .03 & .03 & nd & .01 & .13 & 90.05 \\
\hline Boquira & BIF-Oxide F. & Hematite & nd & .06 & .17 & .34 & 89.36 & .02 & .08 & .01 & nd & .01 & nd & nd & 90.05 \\
\hline Boquira & BIF-Oxide F. & Hematite & nd & .01 & .17 & nd & 89.78 & .03 & .05 & nd & nd & nd & .05 & .04 & 90.13 \\
\hline R.Santana & BIF-Oxide F. & Hematite & .05 & .03 & .61 & nd & 89.31 & .03 & nd & .02 & nd & nd & .02 & nd & 90.07 \\
\hline R.Santana & BIF-Oxide F. & Hematite & .01 & nd & .15 & nd & 89.78 & .02 & nd & .02 & nd & .03 & nd & nd & 90.01 \\
\hline Ibit.-Brumado & BIF-Oxide F. & Hematite & .04 & .13 & .01 & .05 & 89.56 & nd & .14 & nd & .02 & nd & .06 & .01 & 90.02 \\
\hline Caetité & BIMF-Oxide F. & Hematite & nd & nd & .01 & nd & 89.05 & nd & nd & .01 & nd & nd & nd & .69 & 89.76 \\
\hline Caetité & BIMF-Oxide F. & Magnetite & .03 & .01 & .09 & .03 & 91.59 & nd & nd & .04 & nd & nd & nd & .73 & 92.52 \\
\hline Urandí & BIMF-Oxide F. & Magnetite & .02 & .01 & .14 & .05 & 91.89 & .02 & nd & .05 & nd & nd & nd & .65 & 92.83 \\
\hline Caetité & BIMF-Silicate F. & Magnetite & .06 & nd & .34 & .03 & 92.49 & .02 & nd & .04 & nd & nd & nd & .65 & 93.63 \\
\hline L.de Almeida & BIMF-Silicate F. & Magnetite & .66 & .06 & .11 & .19 & 91.49 & .04 & nd & .06 & .05 & nd & .08 & .35 & 93.09 \\
\hline Sento Sé & BIF-Carbon. F. & Calcite & 1.18 & .01 & nd & nd & 1.21 & nd & nd & nd : & 53.04 & nd & .05 & .87 & 56.36 \\
\hline Sento Sé & IPMRCF & Calcite & .76 & .03 & nd & .02 & .70 & .02 & .02 & .02 & 55.19 & nd & .01 & .85 & 57,62 \\
\hline Sento Sé & IPMRCF & Calcite & 1.05 & .04 & .01 & .02 & 1.04 & .01 & nd & .01 & 54.20 & nd & .01 & .97 & 57.36 \\
\hline Sento Sé & IPMRCF & Calcite & 1.22 & .05 & nd & .01 & .98 & nd & .05 & .01 & 54.64 & nd & .01 & .81 & 57.78 \\
\hline Sento Sé & IPMRCF & Calcite & 1.26 & .05 & nd & .01 & .99 & .02 & nd & .01 & 56.48 & .01 & nd & .61 & 59.44 \\
\hline Sento Sé & IPMRCF & Calcite & 1.02 & .03 & .01 & .04 & .84 & .01 & .15 & .02 & 53.87 & nd & .01 & .55 & 56.55 \\
\hline Sento Sé & IPMRCF & Calcite & 1.02 & .02 & nd & .01 & .91 & .02 & nd & nd & 54.54 & .02 & nd & .65 & 57.19 \\
\hline R.de Santana & IPMRCF & Calcite & .89 & .06 & nd & nd & .83 & nd & nd & nd & 53.26 & nd & nd & .58 & 55,62 \\
\hline R.de Santana & IPMRCF & Calcite & .93 & .05 & nd & .02 & .84 & .05 & .04 & .01 & 53.07 & nd & nd & .58 & 55.55 \\
\hline Ibit.-Brumado & IPMRCF & Calcite & .98 & .02 & .01 & .02 & .85 & .03 & .02 & .02 & 54.12 & .01 & nd & .66 & 56.74 \\
\hline Boquira & IPMRCF & Dolomite & 22.15 & nd & .03 & .05 & .55 & nd & nd & nd & 30.25 & nd & nd & .02 & 53.05 \\
\hline Boquira & BIF-Carb. F. & Fe-Dolomite & 16.32 & .02 & .04 & .09 & 3.51 & nd & .01 & nd & 28.72 & nd & .02 & .02 & 48.75 \\
\hline Caetité & BIF-Carb. F. & Fe-Dolomite & 18.99 & nd & .02 & nd & 8.26 & .01 & .01 & nd & 30.16 & nd & nd & .88 & 58.33 \\
\hline Caetité & BIF-Carb. F. & Fe-Dolomite & 18.72 & .01 & nd & nd & 8.14 & nd & .06 & .01 & 30.39 & .01 & nd & .95 & 58.29 \\
\hline Caetité & BIF-Carb. F. & Fe-Dolomite & 18.42 & nd & .02 & nd & 8.14 & nd & nd & nd 2 & 29.97 & nd & nd & .96 & 57.51 \\
\hline Caetité & BIF-Carb. F. & Fe-Dolomite & 18.52 & nd & .01 & nd & 8.08 & .03 & nd & nd & 30.60 & nd & .01 & 1.04 & 58.29 \\
\hline Caetité & BIF-Carb. F. & Fe-Dolomite & 20.58 & .03 & .03 & .15 & 8.15 & nd & nd & .01 & 28.19 & .02 & nd & .95 & 58.11 \\
\hline L.de Almeida & BIF-Carb. F. & Fe-Dolomite & 18.30 & .01 & nd & 3.88 & 8.02 & nd & nd & .01 & 30.35 & nd & .01 & 1.06 & 61.64 \\
\hline L.de Almeida & BIF-Carb. F. & Fe-Dolomite & 18.25 & .02 & nd & 3.63 & 8.27 & .02 & .10 & nd & 30.02 & .02 & nd & .10 & 60.43 \\
\hline L.de Almeida & BIF-Carb. F. & Fe-Dolomite & 17.32 & .01 & nd & nd & 8.14 & nd & nd & nd & 30.03 & .01 & .01 & .10 & 55.62 \\
\hline L.de Almeida & BIF-Carb. F. & Fe-Dolomite & 18.48 & nd & .01 & .02 & 8.34 & nd & .03 & nd & 30.19 & .01 & nd & .98 & 58.06 \\
\hline L.de Almeida & BIF-Carb. F. & Fe-Dolomite & 19.18 & .02 & nd & nd & 8.75 & nd & nd & nd & 30.18 & .01 & nd & .90 & 59.04 \\
\hline L.de Almeida & BIF-Carb. F. & Fe-Dolomite & 18.97 & .01 & nd & .01 & 8.13 & nd & .04 & .01 & 30.12 & .02 & nd & 1.06 & 58.37 \\
\hline Caetité & BIMF-Carb. F. & Fe-Ankerite & 4.47 & .04 & .07 & 4.23 & 25.20 & nd & nd & .02 & 11.27 & .01 & .01 & .75 & 46.07 \\
\hline Caetité & BIMF-Carb. F. & Siderite & 4.00 & .04 & .10 & .11 & 32.04 & nd & nd & .02 & 11.28 & .01 & .02 & .82 & 48.44 \\
\hline Caetité & BIMF-Carb. F. & Siderite & 3.38 & .06 & .16 & .11 & 46.20 & .01 & nd & .01 & 10.56 & nd & .02 & .52 & 50.25 \\
\hline Sento Sé & IPMRCF & Magnesite & 45.38 & .01 & nd & .32 & nd & .02 & nd & .01 & .17 & nd & .01 & .15 & 46.07 \\
\hline Ibit.-Brumado & IPMRCF & Magnesite & 46.31 & .01 & nd & .01 & .41 & nd & nd & nd & .35 & nd & nd & .06 & 47.15 \\
\hline Ibit.-Brumado & IPMRCF & Magnesite & 45.73 & nd & nd & nd & .38 & nd & .01 & nd & .50 & nd & nd & .10 & 46.72 \\
\hline Ibit-Brumado & IPMRCF & Magnesite & 44.96 & nd & .01 & .08 & .32 & nd & .01 & nd & .91 & nd & nd & .04 & 46.33 \\
\hline Ibit.-Brumado & IPMRCF & Dolomite & 25.22 & nd & .01 & .02 & .52 & nd & nd & nd & 30.40 & nd & nd & .15 & 56.32 \\
\hline Sento Sé & BIF-Silicate F. & Trem./Actin. & 18.00 & .34 & .51 & 57.18 & 8.01 & nd & .04 & .03 & 12.59 & .02 & .03 & .24 & 96.99 \\
\hline to Sé & BIF-S & Actin. & 16.46 & .81 & 2.64 & 55.17 & 8.97 & .05 & nd & .11 & 12.36 & .01 & .12 & .28 & 96.98 \\
\hline Sento Sé & BIF-Silicate F. & Trem./Actin. & 16.22 & .90 & 3.12 & 55.00 & 8.80 & nd & nd & .22 & 12.24 & nd & .21 & .25 & 96.96 \\
\hline Boquira & BIF-Silicate F. & Trem./Actin. & 17.38 & .61 & 1.47 & 56.85 & 7.69 & nd & .10 & .06 & 12.61 & .02 & .01 & .21 & 97.01 \\
\hline Boquira & BIF-Silicate F & Grunerite & .15 & .32 & .45 & 47.20 & 49.59 & .01 & nd & .05 & .35 & nd & .01 & .28 & 98.41 \\
\hline Boquira & BIF-Silicate F & Grunerite & .21 & .30 & .28 & 47.36 & 49.52 & .01 & nd & .04 & .28 & .01 & .01 & .30 & 98.32 \\
\hline Boquira & BIF-Silicate F. & Grunerite & .10 & .21 & .39 & 47.49 & 48.97 & nd & .01 & .02 & .19 & .01 & .01 & .17 & 97.57 \\
\hline R. de Santana & BIF-Silicate F. & Hornblende & 13.80 & .98 & 11.13 & 44.34 & 15.55 & .03 & nd & .32 & 11.14 & .06 & .80 & .24 & 98.39 \\
\hline R. de Santana & BIF-Silicate F. & Hornblende & 13.98 & 1.19 & 11.44 & 44.74 & 14.41 & .03 & nd & .37 & 11.13 & .08 & .83 & .20 & 98.40 \\
\hline R. de Santana & BIF-Silicate F. & Hornblende & 13.89 & 1.29 & 11.42 & 44.31 & 15.47 & .03 & nd & .32 & 10.62 & .04 & .79 & .21 & 98.39 \\
\hline
\end{tabular}

among the discussed BIF and either between them and those ones found in the Archean and Early Proterozoic terranes of Canada and South Africa. The BIFs here reported seem intermediate between the Archean Algoma and the Early Proterozoic Superior types. The previous discussions on REE distribution and on the similarities which are locally reported for the lithofacies pointed out four domains of distinct chemical deposition. However recent data as those records of the presence of pyritic facies and massive sulfides in the SobradinhoSalitre SC and the evidence of the occurrence of this facies in the Riacho de Santana SC (Silva and Cunha 1999) make possible to distinguish only two depositional areas of which one is marked by the absence of manganese deposition. The other depositional area is typified by the coeval iron-manganese depositions that are defined into the boundary of the Mn-District outlined by Basilio and Brondi (1986). In that area it is reported (a) a higher content of $\mathrm{Mn}$ in the minerals of the BIF's facies and (b) that the Mn content becomes higher in these minerals (hematite, magnetite, carbonates and silicates) if they occur in the facies that composes the BIMF. The presence of IPMRCF in the stratigraphic column of the SC seems to be one of the most significant identity of these terrains. Dolomite is the most 


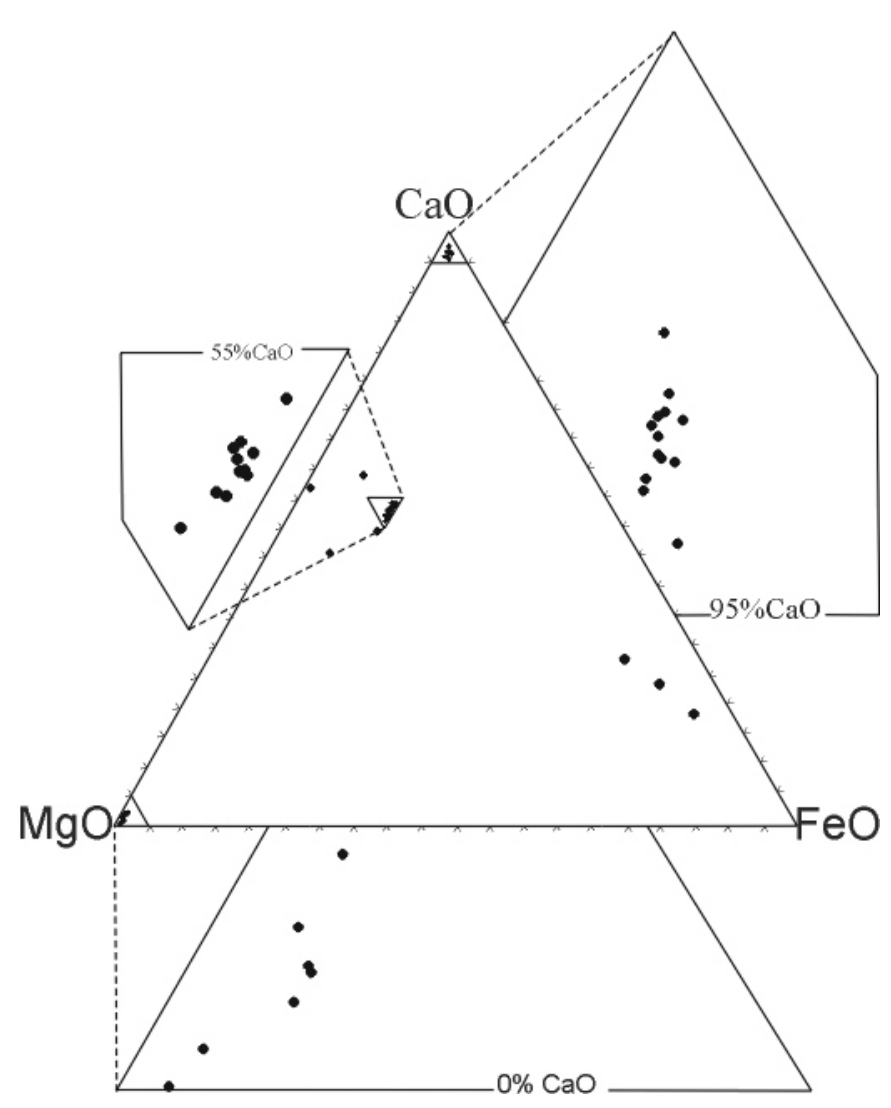

Fig. 4 - Cao-MgO-FeO diagram showing the distribution of the carbonate minerals from the carbonate facies of BIF, BIMF, and from IPMRCF (cf. Table 2).

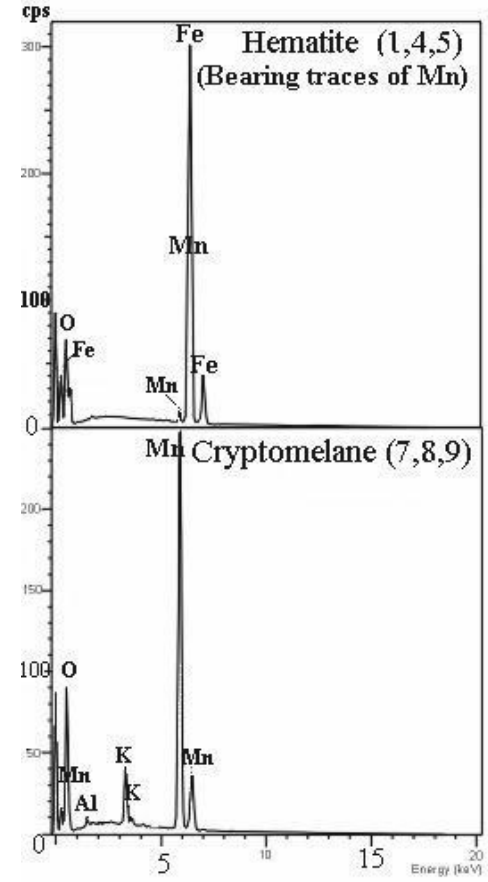

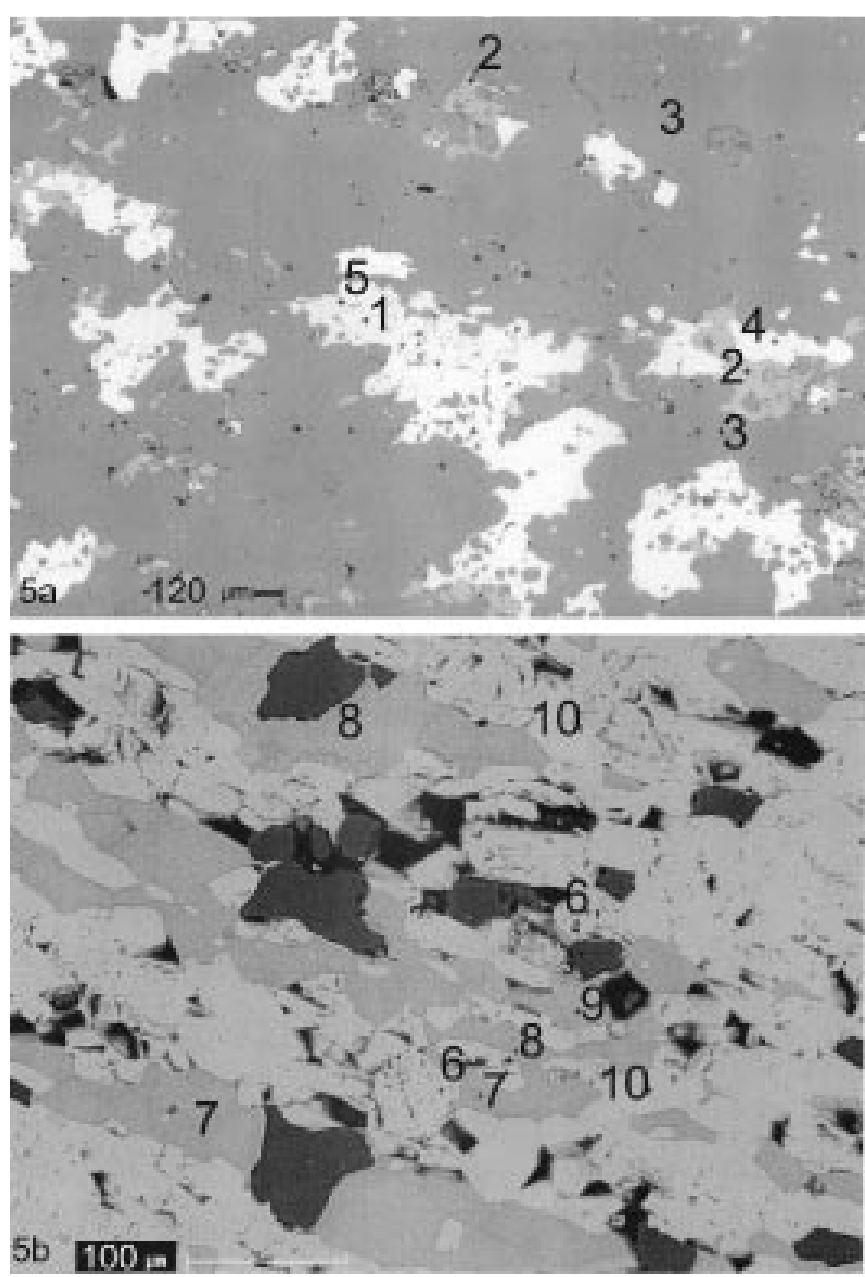

Figure 5 - EDS - Micrographies from polished sections of (A): oxide facies from the Ibitira-Brumado Complex, showing an Amphibole-bearing subbanding. The analised minerals are: Hematite (1,4,5), Tremolite (2) and Quartz (3), and (B) of the oxide facies from the BIMF of the Caetité Complex. The analised minerals are: Mn-Magnetite (6), Cryptomelane (7, 8, 9), Mn-Hematite (10) and Quartz (dark grey), Black = voids.
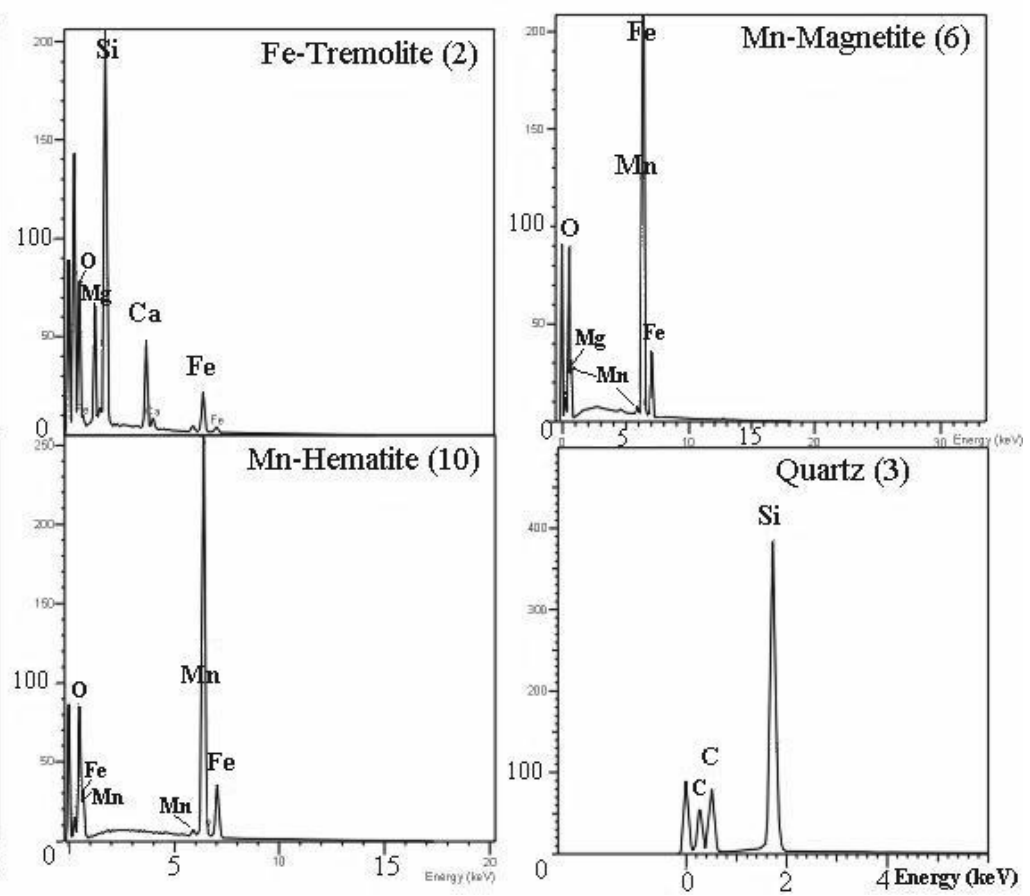

Figure 6-EDS - Spectra for the minerals reported in the Figures 5.A (Hematite 1, 4, 5; Tremolite: 2, and Quartz: 3) and 5. B (Mn-magnetite: 6; Cryptomelane: 7, 8, 9 and Mn-Hematite: 10). 
common carbonate mineral presents in the IPMRCF. The changes in the carbonate composition are locally noticeable by the facies variation as it is reported by the presence of stratiform levels of calcite or magnesite. The overall carbonate composition of the IPMRCF shows an iron content lower than that one reported for the minerals that compose the carbonate facies of BIF and BIMF which are $\mathrm{Fe}$ dolomite, ankerite and siderite (Table 2 and Fig. 4).

The REE data presented by Carvalho and Albuquerque (1996) and Fonseca and Carvalho (1997) for the overall chemical metasediments yield $(\mathrm{Eu} / \mathrm{Sm})_{\mathrm{NC}},(\mathrm{Sm} / \mathrm{Yb})_{\text {C }}$ and $\Sigma$ ETRL/ $/ E T R P$ values respectively of $0.47 ; 4.37$, and 11.46. Also they show high

LREE/HREE ratios and (LREE) $/(\text { HREE) })_{N C}>1$.That is an indication that the dissolved LREE were more efficiently coprecipitated by the original Fe-Mn oxide-hydroxide, carbonate, and silicate gels. The relative abundance of the IPMRCF is suggestive that $\mathrm{CO}_{2}$ played an important rule on the $\mathrm{pH}$ control of the aqueous solution at the time of the deposition, when the $\mathrm{CO}^{-2}$ overwhelms the $\mathrm{HCO}_{3}^{-}$species. This is a process that parallels the $\mathrm{P}_{\mathrm{CO} 2}^{3}$ decreasing and the $\mathrm{pH}$ increasing and it also involves the increasing of the redox potential of the dissolved $\mathrm{Eu}^{++}$, that rests in solution to explain the low $(\mathrm{Eu} / \mathrm{Sm})_{\mathrm{NC}}$ values found in the BIF and BIMF.

CONCLUSIONS Compared to the other chemical facies the BIF predominates in the Boquira $\mathrm{SC}$ and it is also quantitatively significant in the Sento Sé-Remanso and Contendas-Mirante SC. The BIMF predominates in the Caculé and Licinio de Almeida SC. The BMF predominates in the Urandí SC and in many occurrences of the Caetité and Jacarací SC. The IPMRCF is the most abundant chemical lithofacies of the Sento Sé-Remanso and Ibitira-Brumado SC. The most frequent records of hornfels that are derived from BIF and IPMRCF are those reported for the Riacho de Santana SC. The geochemical signatures (data on stable isotopes, REE and other selected trace elements) define the BIF's type as intermediate from the Archean Algoma and the Paleoproterozoic Superior types (Carvalho et al. 1982,1997). The depositional model may be alike to that one of plume applied to subaqueos region of active volcanism which is affected by intense leakage of gaseous-hydrothermal activities. The plume generation and chemical deposition took place troughout an extensive rifted zone of the craton and all the process may last from the end of the Archean to the Early Proterozoic. The local predominance of a given facies is an evidence that the environmental conditions were not homogeneous and not steadfast throughout such an extensive depositional zone.

Aknowledgements To the Brazilian Reseach Council- CNPq. for the financial support (Grant No. 521366/97-6) and Dr. Bernardino Figueiredo (UNICAMP) and Dr. Manoel J.Cruz (UFBA) for the microprobe analises and to two referees of RBG for the critical review of the manuscript.

\section{References}

Angelim L.A.A., Moraes J.F.S., Santos E.J., Silva Filho M. A. 1993. Projeto Levantamentos Geológicos Básicos. Folha Petrolina, CPRM, Recife.

Basílio J.A.F. and Brondi M.A. 1986. Distrito Manganesífero da região de Licínio de Almeida, Bahia. In: Principais Depósitos Minerais do Brasil. Brasilia, DNPM, 2:177 185

Bondelos H.J. 1954. Magnesite Deposits in the Serra das Eguas, Brumado, Bahia, Brazil. Washington, Geological Survey 167 p. (Bol. 975-C).

Bonfim L.F.C., Santos R.A., Oliveira. J.E. 1982. A Seqüência Vulcanossedimentar Guajeru, Sudoeste da Bahia. In: SBG, Congresso Brasileiro de Geologia, 32, Salvador, Anais 1:223-233.

Brito Neves B.B., Cordani U. G., Torquato J. R. F. 1980. Evolução geocronológica do PréCambriano do Estado da Bahia. In: H.A.V. Inda and F.B.Duarte (eds). Geologia e Recursos Minerais do Estado da Bahia. Sec. Minas do Estado da Bahia. Textos Recursos Minerais

Carvalho I.G. 1982. Geology of the Pb-Zn District of Boquira, Bahia, Brazil. In: Congreso Latinoamericano de Geologia, V, Buenos Aires, Actas del V Congreso 02:221-228.

Carvalho I.G. 1998. As ocorrências de talco do Estado da Bahia, Brasil: Considerações genéticas. In: Congresso Latinoamericano de Geologia, X, Buenos Aires, Anais 3:162-166

Carvalho I.G., Zantop H., Torquato J.R.F. 1982. Geologic Setting and Genetic Interpretation of the Boquira Pb-Zn Deposits, Bahia State, Brazil. Revista Brasileira de Geociências, 17:414-425.

Carvalho I.G. and Albuquerque M.A.G. 1996. Contribuição Geoquímica ao Estudo das Deposições Químicas Associadas aos Complexos Metavulcanossedimentares do Proterozóico Inferior do Estado da Bahia. Geochimica Brasiliensis 10:379-400.

Carvalho I.G., Misi A., Iyer S.S.; Tassinari C.C.G. 1997. Lead- and Sulfur- Isotope Investigations of the Boquira Sediment-hosted Sulfide Deposit, Brazil. International Investigations of the Boquira
Geology Review, 39:97-106.

Cunha J.C.C., Bastos C.A. M., Cavalcanti J.C.C., Souza W.S.T. 1981. Projeto JuremaTravessão. CBPM, v. 1 (Final report)

Cunha J.C.C. and Fróes R.J.B. 1994. Komatiitos com textura spinifex do Greenstone Belt de Umburanas, Bahia. Salvador, Companhia Baiana de Pesquisa Mineral, 23 p. (Open File)

Evangelista A.S. 1994. Estudo Geológico e Geoquímico das Formações Ferríferas e Ferromanganesíferas Associadas aos Complexos Metavulcanossedimentares no Estado da Bahia. Curso de Pós-Graduação em Geoquímica e Meio Ambiente/ UFBA, Salvador, Master Thesis, $147 \mathrm{p}$

Figueiroa I. and Silva Filho M.A. 1990. Folha Petrolina (SC 24-V-C-III) Estados de Pernambuco e Bahia. PLGB do Brasil, DNPM/CPRM, 108 p, 2 mapas. (Final report).

Fonseca L.C. and Carvalho I.G. 1997. Estudo Geoquímico para Elementos Maiores e Terras Raras da Formação Ferrífera do Complexo Vulcanossedimentar de Riacho de Santana: comparação com outras formações ferríferas do Cráton do São Francisco no Estado da Bahia. In: SBGq, Congresso Brasileiro de Geoquímica, 7, Salcisco no Estado da Bahia.
vador, Anais 1:424-427.

Inda H.A.V.and Barbosa J.S.F. 1978. Texto Explicativo para o Mapa Geológico do Estado da Bahia. Esc.1:1.000.000. Sec.de Minas e Energia do Estado da Bahia, SME/ CPM, Salvador, $137 \mathrm{p}$

Jardim de Sá E.F., McReath I., Brito Neves B.B., Bartels R.L. 1976. Novos dados geocronológicos sobre o Cráton do São Francisco no Estado da Bahia. In: SBG, Congresso Brasileiro de Geologia, 29, Ouro Preto, Anais 5:185-204.

Kaul P.F.T. 1970. Geologia da Quadrícula de Boquira., Bahia. Recife, SUDENE, Div.Geol.(Brasil). Report 59 (Open file).

Leahy G.A., Conceição H., Rosa M.L.S., Macambira M.J.B., Martin H., Paim M.M., Santos E.B. dos 1998. Maciço Sienítico de Ceraima (Sudoeste da Bahia): Idade, Petrografia e Geoquímica do Magmatismo Pós-orogênico Alcalino-Potássico com Afinidade Lamprofírica. In: Contribuição ao estudo dos granitos e rochas correlatas, Salvador, SBG/Núcleo Ba-Se, p. 61-77 (Publicação Especial No. 5).

Machado R. 1983. Discussão da gênese do proto-minério de manganês da fácies óxidocarbonato denominadas de "Bandarito", Município de Jacarací, Bahia. Revista Brasileira de Geociências 13:99-122.
Marinho M. M. 1991. La séquence volcano-sedimentaire de Contendas-Mirante et la bordure occidentale du bloco Jequié (Cráton du São Francisco, Brésil): Un exemple de transition Archaen-Proterozoique. Univ. Blaise Pascal, Clermont Ferrand II, France. PhD.Thesis, $388 \mathrm{p}$

Marinho M.M., Silva E.F.A., Andrade A.P., Senna Filho A.A., Morais A.M.V., Silva B.C.E., Lopes G.A.C., Soares J.V., Cunha J.C. , Silva, J.C.E., Santos J.G., Cruz M.J. M., Oliveira N.S., Costa P.H., Mota P.R.R., Rangel P.A., Froes R.J.B., Souza S.L., Lago S.E.S., Silveira W.P., Souza W.S.T., Torquato J.R.F., Coutinho J..M.V., Lewis R.W., Monteiro T.P.R. 1979. Projeto Contendas-Mirante. CBPM, Conv. CBPM-SME-Bahia, Salvador, 24 v. (Final report).

Marinho M. M., Silva E.F.A., Lopes G.A.D.C., Soares J. V., Cruz M. J. M. 1980. Projeto Anajé-Caldeirão CBPM, Conv, CBPM-SME-Bahia, Salvador, v. 1, 203 p. (Final report).

Mascarenhas J.F.1976. Estruturas do tipo "Greenstone Belt" no Leste da Bahia. In: SBG, Congresso Brasileiro de Geologia, 29, Ouro Preto, Anais 4: 35-66.

Mascarenhas J.F. and Garcia, T.W. 1989. Mapa Geocronológico do Estado da Bahia. Escala 1:1.000.000: Texto Explicativo. Salvador, SGM/Sec.Minas e Energia.189 p.

Moraes L.C., Martins A.B.M., Sampaio A.R., Gil C.A.A., Andrade Filho E .L. de 1980 Projeto Brumado-Caetité. Salvador, (1a. fase). Conv. DNPM/CPRM (Final report)

Moraes Filho O., Sá Filho R.J., Silva P.E.L, Teixeira L.R. 1981. Prospecção de ouro e cobre no complexo vulcanossedimentar do Barreiro, município de Sento Sé, Bahia. In: I Simp. Mineralização Aurífera do Estado da Bahia, Salvador, CPM/SBG/SME. Resumos e Roteiro de Excursão, p. 5.

Oliveira V.P., Fragomeni L.F.P., Bandeira, C.A. 1997. Depósitos de Magnesita da Serra das Éguas, Brumado, Bahia. In: Principais Depósitos Minerais do Brasil, DNPM 4:219234.
M.M.,

Paim M.M., Conceição H., Rosa M.L.S., Cruz Filho B.E. da, Santos E.B. dos, Peixoto A.de A., Leahy G.A.S. 1998. Maciço de Cara Suja: Petrologia de uma intrusão tardia do batólito monzo-sienítico de Guanambí-Urandí (Sudoeste da Bahia). Implicações geoquímicas para a gênese dos magmas sieníticos alcalino-potássico. In: Contribui-
ão granitos e rochas correlatas, Salvador, SBG/Núcleo Ba-Se, $\mathrm{p}$. çã ao estudo dos granitos

Phaup A.E. 1973. The granitic rocks of the Rhodesian craton. Geol. Soc. South Africa, p. 59-67 (Spec. Publ. No. 9)

Turek A. and Compston W. 1970. Rubidium strontium geochronology in the Kalgoorlie region. Geol. Soc. Australia, 72p. (Special Publ. No. 3).

Pinto M.S., Peucat J.J., Martin H., Sabaté P.1998. Reciclagem da Crosta Continental Arquena: Exemplo do Bloco do Gavião, Bahia, Brasil. In: Contribuição ao estudo dos granitos e rochas correlatas, Salvador, SBG/Núcleo Ba-Se, p.1-19 (Special Paper No. 5)

Ribeiro Filho E. 1973. Geologia da região de Urandí, Estado da Bahia.USP. Boletim do Instituto de Geociências 4:87-95.

Rocha G.M.F. 1983. Caracterização faciológica da formação ferrífera de Boquira, encaixante da mineralização de chumbo e zinco. Curso de Pós-Graduação em Geologia/UFBA., Salvador, Master Thesis. Published in the series: TEXTOS BÁSISec.das Minas e Energia do Estado da Bahia).

Silva M.G. and Cunha J.C. 1999. Greenstone Belts and Equivalent Volcano-Sedimentary Sequences of the São Francisco Craton, Bahia, Brazil-Geology and Mineral Potential. In: (M.G. da Silva and A. Misi, Eds.) Base Metal Deposits of Brazil. MME/CPRM/DNPM. p.92-99.

Souza F.A. 1992. Contribuição ao estudo do intemperismo laterítico de duas regiões do semi-árido baiano: Gentio do Ouro e Sento Sé, Curso de Pós-Graduação em Geociências/UFBA, Salvador, Master Thesis. 158 p.

Souza J.A.D. de, Fernandes F.J., Guimarães J.T., Lopes J.N. 1979. Projeto Colomi: Geologia da Região do Médio São Francisco, Salvador, Convênio DNPM/CPRM. 3v. (Final Report)

Souza J.A.D. de and Teixeira L.R. 1981. Projeto Rio Salitre. Geologia e prospecção geoquímica preliminar no Complexo Rio Salitre. Salvador, CPRM, Conv. SME/ CPRM. (Final Report)

Contribution IGC-165

Received March 5, 2000 Accepted for publication May 10, 2000 